\title{
Occupational Hazards of Medical Group of Women Employees in Healthcare Units in Tamil Nadu, India.
}

\author{
\{Project Funded By: RVPSP Division, DST, New Delhi - 110016\} \\ Dr. D. ASHOK \\ Professor, VIT Business School, VIT University, Vellore - 14, TN, India.
}

\begin{abstract}
In this study, the author focused on the medical group of jobs like 'Doctors and Nurses' employed in health care units. The myriad of occupational hazards to which healthcare workers may be exposed can be classified into five broad categories: biological, chemical, physical, and ergonomic/safety and psycho-social hazards. Based on above hazards sources and the proposition of women employment in nursing related jobs, the researcher had identified women session of employment in medical as their profession as the target group and the research objectives were framed accordingly to explore the details of personnel profile, organizational profile, employment profile, safety and health profile, training programs profile, personal treatment profile and personal occupational experience of women employees in their workplace. This article is focused on the cause and effect relationship between various factors associated with women employees' occupation in nursing homes and their influence in their occupation.
\end{abstract}

Keywords: Physical disablement, health care units, Occupational hazards, Ergonomics, psychosocial working conditions

\section{INTRODUCTION}

A hazard is something that can prove dangerous if not controlled. In order to evaluate the risks involved in an occupation, it is necessary to analyze the occupational hazards and implement appropriate measures to ensure occupational safety. It deals with safeguarding the lives of all those people, who, in some way, to the work environment.

An occupation, by definition is the primary activity of one's life that he/she engages in, to earn money. Every occupation comes along with certain hazards. One should consider the proper safety measures in order to preserve his/her life. It is also the primary responsibility of the employing organizations to look after the safety of their employees. In this context, it is necessary to understand the various hazards that different occupations have. It has also with the welfare of the family members and dependents of the working employees.

Any work-related events place a person at a reasonable anticipated risk of infection, illness or injury. Occupational hazards cause or contribute to the premature death of millions of people worldwide and result in the ill health or disablement of hundreds of millions more each year. As per World Health Organization information, almost 22.5 million DALY (Disability-Adjusted Life Year) and 699,000 deaths are attributable to these risk factors. According to the report, work related injuries causes nearly 310,000 deaths each year, and nearly 146,000 deaths are attributable from the region remains largely un-characterized. However, workers have exposed to a wider range of professional risks including chemical, physical and biological hazards as well as inadequate ergonomic practices and high psychosocial stress.

Thus, the most common operational definition of Occupational hazard could include a working environment/condition that can lead to illness or death. Often, people in jobs which pose a high degree of risk had paid more than similar but less risky jobs to compensate for the danger involved. Therefore, the Occupational hazards include risk of accident and of contracting occupational diseases. The occupational diseases may be defined as health condition such as physical injuries, physical disablement, distressed, exposed to radiation, poisonous gas, and physical difficulties under occupational hazards.

\section{Occupational hazards for Healthcare Employees:}

Healthcare Institutions [1] like Hospitals, Nursing Homes, Clinics and others present numerous hazards in common with other complex application settings and industries as well as having some unique hazards. A great variety of jobs had performed in 'medical groups' in healthcare facilities like, direct patient care, laboratory and research projects and record keeping, waste disposal, front office etc., at the miner part of commitments at the regular intervals in routine assignments. The myriad of occupational hazards to which healthcare workers may be exposed can be classified into five broad categories: biological, chemical, physical, and ergonomic/safety and psycho-social hazards. 
Review of Literature: Following are the research papers/manuals had considered, to complete the research gaps, objectives of the research and testing instruments needed for this study.

Occupational Safety and Health Administration [2] prepared a manual on Guidelines for Nursing Homes Ergonomics for the Prevention of Musculoskeletal Disorders. They covered all relevant aspects of ergonomics and its implementation over prevention of musculoskeletal disorders. National Institute for Occupational Safety and Health [3] prepared a manual on exposure to stress - occupational hazards in Hospital. The purpose of this manual is to identify the sources of occupational stress, identify the adverse health effects of occupational stress, and maintenance work practices to reduce occupational stress. Further, they also added potential adverse health effects of occupational stress like: Psychological (irritability, job dissatisfaction, depression), Behavioural (sleep problems, absenteeism) and Physical (headache, upset stomach, changes in blood pressure). Finally, it added the most effective way of reducing occupational stress by eliminating the stressors by redesigning jobs or making organizational changes. A working manual [4] developed for 'Occupational Health and Safety Management Programme for Nurses'. He discussed on all about the International council of Nurses guidelines for healthy and sustainable health and safety programme for nurses. Further he added about the framework for identifying, assessing and controlling workplace hazards involves four elements namely 'management commitment, employee participation, written occupational health and safety performance and a strong health and safety performance committee formation'. Agnihotram, R.V [5], worked on 'occupational health research in India'. Recent industrialization and globalization are changing the Indian occupational morbidity drastically. Traditionally labour-oriented markets are on change towards more automation and mechanization, at the same time, information about occupational safety, occupational and environmental hazards in the society. This review will provide an overview of existing evidence from community based epidemiological studies and address the growing needs for evidence-based occupational health research in India. Review of all published results. While India experiencing economic transition, occupational research proposal should balance between understanding the modern industrial exposures and health risks of traditional sectors like agriculture and plantations. Strategies like current occupational health legislation, enforcement agency in sub-district level, education to health professionals, need for epidemiological evidence and international collaborations to deal with the situation. Ramsay, J.D [6], presented his views on 'A new look at nursing safety: The development and use of JHAs in the Emergency Department', nationally, a critical nursing shortage looms. In addition to the fact that nurses are increasingly in short supply, the aging of the nursing profession combines to create a daunting challenge to the healthcare field. However, several factors intrinsic to nursing. Presumably, the safety of nurses themselves and eventually, that of their patients, depend directly on the extent to which nurses can understand and manage the diverse occupational hazards specific to jobs. This paper has reviewed the nature and extent of professional nursing hazards and the extent to which current nursing knowledge and job descriptions, nurses to identify and reduce the hazards inherent in their jobs. European Agency for Safety and Health at Work [7], discussed on 'Risk assessment in Healthcare'. The major goal of risk assessment is to promote the relationship between hazards and health outcomes to assess the risk to health from exposure to a hazard (Cox et al, [8]). According to World Health Organization [9], human health risk assessment is "the process that evaluates the nature and likelihood of adverse human health effects from exposure to one or more stressors". They classified the health risk assessment for working environment factors and emotional and agronomical factors. The healthcare sector is one of the largest sectors in Europe. This article outlines the risk factors specific to the healthcare sector and describes practical steps of risk assessment. Risk assessment is a key to preventing and reducing healthcare workers exposure to work hazards. CRISIL report [10] on Crisis's grading for healthcare institutions. In this manual, they discussed on grading scales for different hospital types such as, nursing homes, traditional secondary care, specialty secondary care, and single and multi-specialty tertiary care. Chad J. Roy, [11], discussed on 'Occupational Health and Safety' in the Nursing Homes. They discussed mainly on various physiological and agronomical hazards of employment in nursing homes.

Research Problem: The proverb says, living longer can be a mixed blessing, especially for those so chronically ill or frail that they need round-the-clock assistance with the basic functions of daily living. Absent alternative care, many of these become residents of nursing and personal care facilities, where their physically demanding needs are both a challenge and a hazard to nursing aides and other caregivers. Hospital presents several hazards in common with other complex situation settings. Moreover, the roles of women in society have multifaceted. They need to care dual role at both individual and official. Hence, the researcher has shown significant interest to research on women session of employment as the target group that to by considering the doctors and nurses in particular. 
Objectives of the study: The key research questions on various categories of employment, group of employees employed, importance of safety and health practices, Importance of the training programs and personal experience in business relating to different types of hazards sources.

Following are the operational objectives designed for the study:

1. To understand the patterns of 'Personal profiles, organizational design and job description of the women employees in an identified group in the study area.

2. To measure the 'safety and health' components associated with medical professionals employed in health care units in the study area.

3. To explore the respondents' personal experience towards various category of factors causing occupational hazards in healthcare units, in the study area.

\section{Research Methodology:}

The researcher has adopted the detailed research design. The researcher has attempt to create data structures that describe the existing characteristics that are properly representing the various problems associated with women group of medical professionals employed in health care units in the study area, through generating data structure relating to this study objectives. All information collected from respondent had used to determine 'cause and effect' relationship between various factors associated with women employees' career in nursing homes. This study could used to understand the relationship between the causal factors and the outcome predicted.

The researcher has formulated the research design based on the idea of defining the population. In this study, the researcher has selected the state of Tamil Nadu, India as the geographical area. Further, the researcher had selected two main cities in Tamil Nadu based on the importance and operational advantage of the study namely, the Capital city of the Tamil Nadu (Chennai) and the Fort city of Tamil Nadu (Vellore) as the sample cities in Tamil Nadu for the study. The importance of both cities, identified for the study is highly significant. Both cities have been birthplaces of pioneers in the healthcare industry. Both cities have well connected on road, railways and air services from other parts of India like northern and southern. Thus, it proved a vital gateway to many states like Andhra Pradesh, Karnataka \& Kerala. The most of the employees in healthcare institutions were not only representing the state of Tamil Nadu, but also representing the other closer states like Andhra Pradesh, Kerala and Karnataka.

Population: The research team has decided to review all those women group of medical professionals like doctors and nurses employed in various identified private healthcare units within the study areas as the study population.

\section{Sampling Framework:}

From the representative areas of the study, the researcher has formulated the sampling frame needed for by considering the different sources like the telephone directory, Internet and personal references made by the local professionals. However, the researcher has used census form; to draw respondents from all identified institutions through defined sampling size work. Therefore, this article has confined to only with all permitted group of institutions in the study area. Moreover, for the benefit of the study, the researcher has considered all those women employees having five and above years of combined professional experience in their area only considered as samples for this study.

Tool of Data Collection: The designed instrument has initially administered to the pilot study to assess the suitability of the questions used for the study objectives. The researcher has prepared 600 questionnaires to collect the samples under medical professional of women employees.

\section{Sample Size frame work:}

The required sample size had drawn from all those institutions that have officially permitted to draw samples using purposive sampling under non-probability method. The sampling has done during the first quarter of the year 2010. The total number of samples collected from each representative area of the paper as shown in the table: one

Table: 01 Sampling Size framework

\begin{tabular}{|l|c|l|c|}
\hline \multirow{2}{*}{ Representative area } & \multicolumn{2}{|l|}{$\begin{array}{l}\text { No. of Private Institutions } \\
\text { covered }\end{array}$} & $\begin{array}{l}\text { Total } \\
\text { Sample representation } \\
\text { Collected \& used from } \\
\text { each study area }\end{array}$ \\
\hline $\begin{array}{l}\text { Permission } \\
\text { obtained }\end{array}$ & $\begin{array}{l}\text { Not } \\
\text { permitted }\end{array}$ \\
\hline $\begin{array}{l}\text { Chennai District } \\
\text { (Capital City of TN) }\end{array}$ & 30 & 17 & $\mathbf{3 3 0}$ \\
\hline $\begin{array}{l}\text { Vellore District } \\
\text { (Fort City of TN) }\end{array}$ & 29 & 01 & $\mathbf{2 0 0}$ \\
\hline Total samples & $\mathbf{5 9}$ & $\mathbf{1 8}$ & $\mathbf{5 3 0}$ \\
\hline
\end{tabular}

Source: Data frame work 
The Reliability Test: The researcher had attempted to identify the alpha standards to assess the reliability part of research tool by applying the Cronbach's Alpha test in the study areas namely Chennai and Vellore (TN), India respectively as shown in the table: $\mathbf{2}$. The value of alpha (0.837), clearly indicates the degree of reliability of the internal consistency among the variables used in this study.

Table: 2 Combat's Alpha Reliability Test

\begin{tabular}{|l|c|}
\hline Representative Area & Total Samples \\
\hline $\begin{array}{l}\text { Chennai, TN India and } \\
\text { Vellore City TN, India }\end{array}$ & $\mathbf{5 3 0}$ \\
\hline
\end{tabular}

Source: SPSS

Statistical tools for Analyses: Depending on the objectives of the study, and the nature of information structure, the researcher had used frequency distribution, cross-tabulation, weighted average method and ANOVA analysis to extract the relevant information.

\section{Analysis \& Findings Of The Study:}

The major findings of the study revealed that, the patterns of 'Personal profiles', employment profiles' and safety and health related components associated with medical status of women employed in the study area and to assess respondents personal experience towards various occupational hazards identified for the study purpose.

Personal Profile of Women Employees: Out of total respondents, about 46.4 percent of the respondents recorded under the age group of 20-40 years and followed by 35.28 percent witnessed their age group between 31-40 years. Around 61.88 percent had fallen under the status of married variety and balance of 35.47 per cent witnessed under bachelor category. Majority (54.33 per cent) of the respondents did not have any dependence under their care. Further, among the married category, around 34 percent and 22 per cent had blessed with $2-4$ children and one child at home respectively. Among the respondents, majority 80 percent had qualified as Diploma holders and around 20 per cent had acquired Graduates and above as their eligibility to promote the employment.

\section{Employment Profile of Women Employees:}

Around 60 percent of the respondents had an overall record between 5- 10 years of services. The balance of 40 per cent had more than 10 yrs of their working experience. About 60 per cent had recorded their existing employment period as less than 5 years in their own business. Thus, the scope of mobility of staff within the sector was seems to be encouraging. Majority ( 66 per cent) of the respondents had worked in various multi specialty hospitals and balance of them had recorded their presence in various nursing homes and clinics respectively. Among the medical professionals' scenario, about 90 percent had supported with nurses and balance of 10 per cent only by female doctors. Thus, the ratio of 9:1 had maintained in this study i.e., every nine nursing staff, one female doctor group has represented. Since, the study had conducted among the private health care institutions in the study area; all of them had come under the private employees. The nature of experience in their business class had covered to both types of treatment like inpatient and outpatient in their respective organization. Majority (32.26 per cent) stated that, they had more than $50-100$ beds coverage been present in their organization. Further, around 43 per cent stated that, they had more than 150 beds in their organization, out of which 16 percent had more than 200 beds coverage. Hence, the survey results had generously supported with all types of Organizations directly from small to large in order. Among the total respondents, around 70 percent had their permanent position and balance 30 per cent had in confirmation duration of their employment. Nearly 90 percent of the respondents had agreed that, they were working between 5 to 10 hours per day also, around 60 percent of the respondents stated that, they had been working in the night shifts for more than three times in a month and balance of 40 percent had worked in General Shifts only. Among the medical group, 85 percent of them have been working for eight hours duration in a shift and all of them agreed that, they were working only one shift in a day basis. Further, around 45 percent of the respondents had supported by Compensatory leave for their each night shift in a monthly basis. Regarding the compensation package, around 70 percent had their income with agreed Basic Pay, out of which, 30 percent had supported with one or more components like, DA, HRA, CCA etc. Around 50 percent had agreed that, they were eligible for Employees Provident Fund (EPF) deductions from their salary. Thus, it proved, the sector had supported with 50 per cent job security in total, through monitoring the statutory obligations needed for employment. Among the Medical Group, around 60 percent had accepted that, they had various combinations of annual leave facilities like casual/personal leave; earn leave and medical leave to supports for their professional carrier. 



\begin{tabular}{|l|c|c|c|c|c|c|c|}
\hline Cholesterol & $\begin{array}{c}\mathbf{1 1} \\
\mathbf{( 2 . 0 7 )}\end{array}$ & $\begin{array}{c}519 \\
(97.9)\end{array}$ & $\begin{array}{c}6 \\
(54.6)\end{array}$ & $\begin{array}{c}5 \\
(45.45)\end{array}$ & & - & - \\
\hline Diabetes & $\mathbf{3 2}$ & 498 & 5 & 19 & 5 & - & 3 \\
& $\mathbf{( 6 . 0 )}$ & $(94.0)$ & $(15.6)$ & $(59.3)$ & $(15.6)$ & & $(9.37)$ \\
\hline $\begin{array}{l}\text { Cardiovascular } \\
\text { diseases }\end{array}$ & $\mathbf{5}$ & 525 & 4 & 1 & - & - & - \\
\hline Stroke / & $\mathbf{( 0 . 9 4 )}$ & $(99.05)$ & $(80.0)$ & $(20.0)$ & & & \\
Paralysis & $\mathbf{1}$ & 529 & 1 & - & - & - & - \\
\hline Respiratory & $\mathbf{( 0 . 1 9 )}$ & $(99.8)$ & $(100)$ & & & & - \\
Disease & $\mathbf{1 9}$ & 511 & 10 & 7 & 2 & - & - \\
& $(96.4)$ & $(52.6)$ & $(36.8)$ & $(10.5)$ & & \\
\hline $\begin{array}{l}\text { Needle stick } \\
\text { injuries }\end{array}$ & $\mathbf{7 4}$ & 456 & 44 & 14 & 15 & 1 & - \\
\hline Skin diseases & $\mathbf{2 2}$ & 508 & 10 & 3 & 2 & 7 & - \\
& $\mathbf{( 4 . 1 5 )}$ & $(95.84)$ & $(45.45)$ & $(13.6)$ & $(9.09)$ & $(31.8)$ & \\
\hline $\begin{array}{l}\text { Menstrual } \\
\text { irregularities }\end{array}$ & $\mathbf{3 0}$ & 500 & 16 & 11 & 3 & - & - \\
\hline Sleep disorders & $\mathbf{( 5 . 6 6 )}$ & $(94.34)$ & $(53.33)$ & $(36.6)$ & $(10)$ & & \\
\hline
\end{tabular}

Source: Primary data

As stated in table 4, the medical group of respondents had supported habitually all the 'Health' related measures under consideration had shown the 'reserved level' of involvement in occupational hazards in their professional carrier. However, the intensity of health problems faced by the medical group of respondents had shown at the minimum amount of evidence only. Among the factors enlisted under the health related issues, 14 per cent each, had their personal experience on account of 'Needle Stick injuries' and 'sleep disorder' during their occupation. All other types of health related issues under the study like Hypertension (4.33\%), Cholesterol (2.07\%), Diabetes (6.0\%), Cardio vascular diseases (1.0\%), Stroke / Paralysis (0.19\%), Respiratory disease (3.6\%), Skin diseases (4.15\%), and Menstrual irregularities (5.66) had supported extremely minimum amount of subsistence. Though, it looked different, it might be true because, the majority of the respondents say, 82 per cent had come under the age group, up to 40 years and more so, by means of personal or professional support, they would have underwent some self-preventive action needed to overcome such situation.

The study also discovered the magnitude of origin of hazards infectious due to viral, bacterial, Parasitic and fungal organism among the medical status of women employees. One fourth (25 per cent) of the respondents, had recorded their experience, once in a year with bacterial contamination. Followed by one fifth of them (20 per cent) had supported their experience with viral infections, out of which, 70 per cent got affected once in a year and 20 per cent and 10 per cent, each had, with 2 to 4 times and more than 5 times in a year respectively. Further, up to 15 per cent had accounted their hazards source due to parasitic infections, out of which slightly higher than fifty per cent had experienced such infections once in a year and balance of them felt the same more than 2 to 7 times in a year. Followed by, slightly higher than 10 per cent had their experience with fungal infections, out of which slightly lower than 50 per cent had agreed their such event once in a year and slightly higher than 50 per cent had the same event more than 2 to 7 times in a year. This is reasonably feasible due to self negligence of women employees not using security measures against air, water, blood fluid and other source of contamination possible during their working hours.

\section{Safety Measures and Training Sources Associated with Employment:}

Around 70 percent had affirmed that, using 'safety equipments' during working time had made compulsory. Further interestingly, around 80 percent had agreed that, all of them were using such security related equipments by their own interest and added further, every one of them sensed personally, they had satisfactorily recognized the benefits of using such security measures. Further, almost all of them had confirmed, there is no penalty enforced by their employers or authorities for not using the security measures during the working time. This clearly confirms that, all of them using such safety units as part of their self interest / professional regulation, rather not for any put in force made or out of fear. Regarding the preparation programs attended, around one fifth of employees had obtained approval from their respective institution to undertake various training programs under the generic topics on 'Safety related' training program, 'best practices' program and 'health related' programs conducted by various governmental and nongovernmental sources.

Women Related Gynaecological Problems Associated with Medical Profession: Since, this study had focused on women employees in healthcare sectors, the effort has made to see if any effect of gynaecological problems faced by women employees due to physical or mental stress. From the results, around 60 percent of 
Occupational Hazards of Medical Group of Women Employees in Healthcare Units in Tami lNadu

medical group had never so for faced any gynaecological problem in their life span. However, they made minor commitment up to four percent and two percent each, had their experience with spontaneous abortions and miscarriages in their life span. Finally, around 50 percent of the respondents had their health related discussion as 'Inpatient' category and they had self managed for their financial requirement through private sources.

Personal experience of (Medical) Women Employees in their Occupation: As stated in the objective of the study, the researcher had identified six set of factors namely; Physical, Chemical, Biological, Health related, Psycho-social and Professional vs. Personal based on different related reviews collected from secondary source of information.

Table 5: Personal Experience of (Medical) Women Employees facing Occupational Hazards

\begin{tabular}{|c|c|c|c|c|c|c|c|c|}
\hline \multirow{2}{*}{$\begin{array}{l}\text { Scaling factors } \\
\text { Weight age }\end{array}$} & \multirow{2}{*}{$\begin{array}{l}\text { Not } \\
\text { at all } \\
0\end{array}$} & \multirow{2}{*}{$\begin{array}{l}\text { Rarel } \\
\mathbf{y}\end{array}$} & \multirow{2}{*}{$\begin{array}{l}\text { Occasio } \\
\text { n } \\
2\end{array}$} & \multirow{2}{*}{$\begin{array}{l}\text { Often } \\
\\
3\end{array}$} & \multirow{2}{*}{$\begin{array}{l}\text { Ver } \\
\text { y } \\
\text { Ofte } \\
\text { n } \\
4\end{array}$} & \multicolumn{3}{|c|}{ Weighted Average Score } \\
\hline & & & & & & $\begin{array}{l}\text { Total } \\
\text { Score }\end{array}$ & $\begin{array}{l}\text { Total } \\
\text { Respond } \\
\text { ents }\end{array}$ & $\begin{array}{l}\text { Averag } \\
\text { e Score }\end{array}$ \\
\hline \multicolumn{9}{|c|}{ I. Physical Hazards } \\
\hline $\begin{array}{l}\text { Physical } \\
\text { injuries }\end{array}$ & - & 333 & 246 & 156 & 88 & 823 & 530 & 1.55 \\
\hline $\begin{array}{l}\text { Physical } \\
\text { disablements }\end{array}$ & - & 473 & 66 & 30 & 56 & 625 & 530 & 1.17 \\
\hline $\begin{array}{l}\text { Anxiety, mental } \\
\text { stress, } \\
\text { depressions }\end{array}$ & - & 336 & 258 & 138 & 76 & 808 & 530 & 1.52 \\
\hline $\begin{array}{l}\text { Electrical } \\
\text { shock. }\end{array}$ & - & 485 & 70 & 9 & 28 & 592 & 530 & 1.11 \\
\hline $\begin{array}{l}\text { Exposed to } \\
\text { radioisotope } \\
\text { radiation }\end{array}$ & - & 441 & 128 & 42 & 44 & 655 & 530 & 1.23 \\
\hline $\begin{array}{l}\text { Exposed very } \\
\text { often to UV } \\
\text { radiation, }\end{array}$ & - & 473 & 88 & 15 & 32 & 608 & 530 & 1.14 \\
\hline \multicolumn{9}{|c|}{ II. Chemical Hazards } \\
\hline $\begin{array}{l}\text { Exposed to } \\
\text { poisonous gas }\end{array}$ & - & 494 & 46 & 24 & 20 & 584 & 530 & 1.10 \\
\hline $\begin{array}{l}\text { Skin related } \\
\text { problems }\end{array}$ & - & 424 & 118 & 81 & 80 & 703 & 530 & 1.32 \\
\hline $\begin{array}{l}\text { ENT related } \\
\text { problems }\end{array}$ & - & 383 & 228 & 57 & 56 & 724 & 530 & 1.36 \\
\hline \multicolumn{9}{|c|}{ III. Biological Hazards } \\
\hline $\begin{array}{l}\text { Infectious } \\
\text { disease }\end{array}$ & - & 380 & 162 & 135 & 96 & 773 & 530 & 1.45 \\
\hline $\begin{array}{l}\text { Faced the risk } \\
\text { of Infections }\end{array}$ & - & 405 & 130 & 120 & 80 & 735 & 530 & 1.38 \\
\hline $\begin{array}{l}\text { Faced physical } \\
\text { difficulties- } \\
\text { ergonomic } \\
\text { design }\end{array}$ & - & 418 & 140 & 63 & 84 & 705 & 530 & 1.33 \\
\hline $\begin{array}{l}\text { Low energy in } \\
\text { workplace. }\end{array}$ & - & 313 & 256 & 162 & 140 & 871 & 530 & 1.64 \\
\hline $\begin{array}{l}\text { Lower back } \\
\text { pain }\end{array}$ & - & 295 & 244 & 189 & 200 & 928 & 530 & 1.75 \\
\hline $\begin{array}{l}\text { Physically } \\
\text { stressed }\end{array}$ & - & 292 & 220 & 201 & 244 & 957 & 530 & 1.80 \\
\hline $\begin{array}{l}\text { Mentally } \\
\text { Stressed }\end{array}$ & - & 381 & 198 & 90 & 80 & 749 & 530 & 1.41 \\
\hline
\end{tabular}




\begin{tabular}{|c|c|c|c|c|c|c|c|c|}
\hline \multicolumn{9}{|c|}{ IV. Health related Hazards } \\
\hline $\begin{array}{l}\text { headache \& } \\
\text { body ache }\end{array}$ & - & 207 & 368 & 267 & 200 & 1042 & 530 & 1.96 \\
\hline $\begin{array}{l}\text { Shortness of } \\
\text { breath in work } \\
\text { area. }\end{array}$ & - & 399 & 198 & 63 & 44 & 704 & 530 & 1.32 \\
\hline $\begin{array}{l}\text { Menstrual } \\
\text { irregularity }\end{array}$ & - & 471 & 70 & 45 & 36 & 622 & 530 & 1.17 \\
\hline Osteoporosis & - & 475 & 68 & 24 & 52 & 619 & 530 & 1.16 \\
\hline \multicolumn{9}{|c|}{ V. Psycho-Social hazards } \\
\hline $\begin{array}{l}\text { Physical } \\
\text { violence at the } \\
\text { workplace }\end{array}$ & - & 393 & 206 & 48 & 72 & 719 & 530 & 1.35 \\
\hline $\begin{array}{l}\text { Psychological } \\
\text { /emotional } \\
\text { abuse }\end{array}$ & - & 385 & 210 & 75 & 60 & 730 & 530 & 1.37 \\
\hline $\begin{array}{l}\text { Gender } \\
\text { discrimination }\end{array}$ & - & 468 & 88 & 36 & 24 & 616 & 530 & 1.16 \\
\hline $\begin{array}{l}\text { Personal } \\
\text { exploitation }\end{array}$ & - & 454 & 118 & 27 & 32 & 631 & 530 & 1.19 \\
\hline $\begin{array}{l}\text { Sexual } \\
\text { harassment. }\end{array}$ & - & 485 & 60 & 18 & 36 & 599 & 530 & 1.13 \\
\hline $\begin{array}{l}\text { More } \\
\text { discomfort }\end{array}$ & - & 428 & 92 & 81 & 116 & 717 & 530 & 1.35 \\
\hline $\begin{array}{l}\text { Occupation is } \\
\text { unsafe for } \\
\text { women } \\
\text { employees. }\end{array}$ & - & 453 & 98 & 30 & 72 & 653 & 530 & 1.23 \\
\hline \multicolumn{9}{|c|}{ VI. Professional Vs. personal Hazards } \\
\hline $\begin{array}{l}\text { Cannot cope up } \\
\text { with work and } \\
\text { family }\end{array}$ & - & 288 & 256 & 237 & 140 & 921 & 530 & 1.73 \\
\hline $\begin{array}{l}\text { Lack of support } \\
\text { from family } \\
\text { members }\end{array}$ & - & 395 & 182 & 93 & 52 & 722 & 530 & 1.36 \\
\hline $\begin{array}{l}\text { Irregular } \\
\text { working hours }\end{array}$ & - & 356 & 184 & 126 & 160 & 826 & 530 & 1.55 \\
\hline $\begin{array}{l}\text { Worried about } \\
\text { the welfare of } \\
\text { children when } \\
\text { at work. }\end{array}$ & - & 329 & 126 & 198 & 288 & 941 & 530 & 1.77 \\
\hline $\begin{array}{l}\text { Work only to } \\
\text { support family. }\end{array}$ & - & 224 & 220 & 309 & 372 & 1125 & 530 & 2.12 \\
\hline $\begin{array}{l}\text { Mental and } \\
\text { physical } \\
\text { harassment in } \\
\text { workplace. }\end{array}$ & - & 379 & 192 & 99 & 88 & 758 & 530 & 1.43 \\
\hline $\begin{array}{l}\text { Society has } \\
\text { negative } \\
\text { opinion in this } \\
\text { kind of job. }\end{array}$ & - & 437 & 98 & 30 & 136 & 701 & 530 & 1.32 \\
\hline
\end{tabular}

Source: Primary Data

Among the various divisions mentioned above, the researcher has identified about ten factors, which had sporadic degree of influence over occupational hazards specifically. They are: Physical injuries due to minor slips, stabs and cuts, burns, scalds, had accounted for 1.55/4.00 each, respectively. Anxiety, mental stress, 
depressions \& emotional disturbance each, had accounted for 1.52/4.00 each respectively. Experienced a sense of low power had accounted for 1.64/4.00 and similarly, experienced lower back pain due to carrying heavy loads of work in a standing posture had also gained 1.75/4.00 The women employees had their experience on the physically stressed due to night shift and overtime work had counted for 1.80/4.00. Employees' personal experience with frequent headache \& body ache due to work stress had accounted for $1.96 / 4.00$. The women employees had faced difficulties to cope up with industry demands in their employment and family responsibilities at home had supported with 1.73/4.00. Similarly they faced difficulties due to irregular working hours to compromise their family responsibilities had accounted for 1.55/4.00. Respondents worried about the welfare of their children, when they were at work supported with $1.77 / 4.00$. Similarly they had mentally prepared to work for economical returns needed for supporting their family to the turn of 2.12/4.00 as shown in table 5

\section{ANOVA Test Results:}

In order to make necessary confirmation on the study results, the researcher has further attempted to cross tabulate the relationship between independent factors and the dependent factor identified in this study. Following were the independent factors like, age group, total employment experience, marital status, educational qualification and number of institutions worked so for. For the operational purpose, the researcher has formulated the research hypothesis to know the reality of association of 'independent factors' over the dependent factor of personal experience of employees over the sources of occupational hazards by using the ANOVA test.

$\mathrm{H} 0=$ There is no association of 'Independent factors' with personal experience on occupational Hazards in Health care units.

$\mathrm{Ha}=$ There is a definite association of independent factors with personal experience on occupational hazards in health care units.

The researcher has applied ' $F$ test' for knowing the association of various independent factors over the variables influencing the occupational hazards. The calculated value and hypothetical value of those associations were given below in the table 6 . The calculated value of $\mathrm{F}$ test is less than hypothetical value, at 5 percent confidence level, then the null hypothesis for the study has rejected or the alternative hypothesis has accepted. Hence, all those variables exhibited in the table with less than .05 had shown significance in their association with respective variables.

Table 6: The Relationship between Identified Independent Variables with Own Experience on variables influencing Occupational Hazards among Women Employees'

\begin{tabular}{|c|c|c|c|c|c|c|c|c|c|c|}
\hline \multirow{2}{*}{$\begin{array}{l}\text { Dependent Variables } \\
\\
\text { Personal Experience } \\
\text { over Occupational } \\
\text { Variables } \\
\end{array}$} & \multicolumn{2}{|l|}{ Age } & \multicolumn{2}{|c|}{$\begin{array}{l}\text { Working } \\
\text { Experience }\end{array}$} & \multicolumn{2}{|c|}{$\begin{array}{l}\text { Marital } \\
\text { Status }\end{array}$} & \multicolumn{2}{|c|}{ Qualification } & \multicolumn{2}{|c|}{$\begin{array}{l}\text { No. } \\
\text { Institutions } \\
\text { worked }\end{array}$} \\
\hline & F test & Sig. & F test & Sig. & $F$ test & Sig. & $F$ test & Sig. & $F$ test & Sig. \\
\hline $\begin{array}{l}\text { Physical Injuries due to } \\
\text { minor slips, stabs, cuts }\end{array}$ & .298 & .827 & 1.336 & .085 & 1.120 & .340 & .194 & .941 & 3.639 & .003 \\
\hline $\begin{array}{l}\text { Physical disablements } \\
\text { due to bone fracture, } \\
\text { bone dislocation }\end{array}$ & 948 & .417 & 1.015 & .448 & .467 & .705 & 1.053 & .379 & 1.762 & .119 \\
\hline $\begin{array}{l}\text { Distressed due to } \\
\text { anxiety, mental stress. }\end{array}$ & .512 & .674 & 1.187 & .205 & .225 & .879 & 1.318 & .262 & 3.928 & .002 \\
\hline Electric shock & 2.880 & .035 & 1.074 & .353 & .365 & .778 & 1.102 & .355 & 2.595 & .025 \\
\hline $\begin{array}{l}\text { Exposed to radiation } \\
\text { radioisotopes sources }\end{array}$ & 3.137 & .025 & .816 & .786 & .388 & .762 & .336 & .854 & 1.213 & .302 \\
\hline UV radiation & .935 & .423 & 1.172 & .221 & 2.920 & .034 & 1.713 & .146 & .606 & .696 \\
\hline $\begin{array}{l}\text { Exposed to poisonous } \\
\text { gas in workplace }\end{array}$ & . 472 & .702 & .912 & .628 & .974 & .405 & .378 & .825 & 1.509 & .185 \\
\hline $\begin{array}{ll}\text { Experienced } & \text { skin } \\
\text { related problems } & \end{array}$ & .279 & .841 & 1.022 & .436 & .234 & .873 & 1.920 & .106 & 5.107 & .000 \\
\hline $\begin{array}{l}\text { Experienced irritation } \\
\text { of eyes, nose, throat }\end{array}$ & .336 & .800 & 2.130 & .000 & .234 & .873 & .600 & .663 & 2.426 & .034 \\
\hline $\begin{array}{l}\text { Risk of contacting an } \\
\text { infectious disease }\end{array}$ & .718 & .542 & 1.409 & .052 & .776 & .508 & 6.400 & .000 & 3.976 & .002 \\
\hline $\begin{array}{l}\text { Exposure to blood, } \\
\text { body fluids, or tissue, }\end{array}$ & .512 & .674 & 1.662 & .007 & .529 & .663 & 3.398 & .009 & 1.598 & .159 \\
\hline
\end{tabular}


Occupational Hazards of Medical Group of Women Employees in Healthcare Units in Tami lNadu

\begin{tabular}{|c|c|c|c|c|c|c|c|c|c|c|}
\hline specimen & & & & & & & & & & \\
\hline $\begin{array}{l}\text { Physical Difficulties } \\
\text { due to lack of } \\
\text { ergonomic design }\end{array}$ & 3.546 & .014 & .710 & .912 & 1.886 & .131 & 1.116 & .348 & 1.797 & .112 \\
\hline $\begin{array}{l}\text { A sense of low energy } \\
\text { in workplace }\end{array}$ & 3.476 & 016 & 1.427 & 046 & 1.232 & 297 & .875 & 479 & 1.562 & 169 \\
\hline $\begin{array}{l}\text { Back pain to carrying } \\
\text { heavy loads of work }\end{array}$ & 2.096 & .100 & 1.917 & .001 & 1.503 & .213 & 1.755 & .137 & 984 & .427 \\
\hline $\begin{array}{l}\text { Stress due to night shift } \\
\text { and overtime work. }\end{array}$ & 1.669 & .173 & 1.400 & 055 & 1.010 & 388 & 691 & .598 & 1.157 & .330 \\
\hline $\begin{array}{l}\text { Stressed due to severely } \\
\text { disturbed patients }\end{array}$ & 1.307 & .271 & 1.456 & .037 & .434 & .728 & .307 & .873 & 4.300 & .001 \\
\hline $\begin{array}{l}\text { Experienced headache } \\
\text { and body ache }\end{array}$ & 5.602 & .001 & 1.318 & .095 & 2.540 & .056 & 1.916 & 106 & 2.645 & .022 \\
\hline $\begin{array}{l}\text { Shortness of breath in } \\
\text { work area }\end{array}$ & 1.549 & .201 & 1.185 & .206 & .788 & .501 & .965 & .426 & .988 & .424 \\
\hline $\begin{array}{l}\text { Menstrual irregularity } \\
\text { due to occupation }\end{array}$ & .406 & .749 & 1.321 & .093 & 237 & .870 & .566 & .687 & 2.549 & .027 \\
\hline $\begin{array}{l}\text { Faced Osteoporosis due } \\
\text { to low bone mineral } \\
\text { density }\end{array}$ & 2.481 & .060 & 1.653 & .008 & 1.295 & .275 & 1.358 & .247 & 2.918 & .013 \\
\hline $\begin{array}{l}\text { Physical Violence from } \\
\text { patients and others }\end{array}$ & 25 & .289 & 3 & 008 & 1.296 & .275 & .050 & 381 & .717 & 611 \\
\hline $\begin{array}{l}\text { Psychological } \\
\text { emotional abuse at } \\
\text { workplace }\end{array}$ & 2 & .752 & 1.443 & .041 & .800 & .494 & .321 & .864 & 1.721 & 128 \\
\hline Personal discrimination & 46 & .586 & 534 & 21 & 186 & 66 & .745 & .561 & 1.128 & 344 \\
\hline $\begin{array}{l}\text { l Exploitation at } \\
\text { kplace }\end{array}$ & 443 & .0 & 6 & 00 & 6 & .581 & 50 & .008 & 42 & .392 \\
\hline $\begin{array}{ll}\text { Experienced } & \text { sexual } \\
\text { harassment }\end{array}$ & .496 & .685 & 1.620 & .010 & .938 & .422 & .795 & .529 & 6.611 & .000 \\
\hline $\begin{array}{l}\text { Discomfort due to } \\
\text { travel time }\end{array}$ & 3.828 & .010 & 1.514 & .024 & .628 & .597 & 694 & .150 & .444 & .818 \\
\hline $\begin{array}{l}\text { Unsafe for women } \\
\text { employees }\end{array}$ & .171 & .916 & 199 & .191 & .709 & .547 & 1.037 & .387 & .081 & .000 \\
\hline $\begin{array}{l}\text { Difficulties to cope up } \\
\text { with work demands and } \\
\text { family responsibilities }\end{array}$ & 7.397 & .000 & 2.250 & .000 & 3.007 & .030 & 4.146 & .003 & 2.217 & .051 \\
\hline $\begin{array}{l}\text { Lack of support by } \\
\text { family members }\end{array}$ & 1.335 & .262 & 1. & .081 & 3.051 & .028 & .245 & .291 & 268 & .047 \\
\hline $\begin{array}{l}\text { Irregular working hours } \\
\text { to compromise family }\end{array}$ & $\begin{array}{c}14.16 \\
6\end{array}$ & .000 & 2 & .000 & $\begin{array}{c}20.87 \\
2\end{array}$ & .000 & 868 & .115 & 1.061 & .381 \\
\hline $\begin{array}{l}\text { Worried about the } \\
\text { welfare of children }\end{array}$ & $\begin{array}{c}33.27 \\
3\end{array}$ & 000 & 8 & .000 & $\begin{array}{c}49.33 \\
4\end{array}$ & .000 & 976 & .097 & 3.580 & .003 \\
\hline $\begin{array}{l}\text { work only to meet out } \\
\text { economic returns }\end{array}$ & 4.628 & .003 & 2.011 & .000 & 8.063 & .000 & 2.646 & .033 & 1.687 & .136 \\
\hline $\begin{array}{l}\text { Mental and physical } \\
\text { harassment }\end{array}$ & 1.118 & .341 & 1.663 & .007 & 2.202 & .087 & 2.034 & .088 & 14.86 & .000 \\
\hline $\begin{array}{l}\text { Negative opinion about } \\
\text { women work }\end{array}$ & 2.038 & .108 & 1.132 & .270 & .377 & .769 & 1.145 & .334 & 5.269 & .000 \\
\hline
\end{tabular}

Source: Primary data

The results of the ANOVA test clearly showed that, only few set of factors among the occupational hazards were shown highest level of significance with each independent factors of our choice as shown in the above table.

Among the MEDICAL GROUP of employees, the relationship between 'Age Group' of the respondents with personal experience of different hazards associated with their occupation had shown highest level of significance with the following ten hazards factors.

As the result, the null hypothesis had rejected by accepting the alternate hypothesis. Therefore, the age group of the respondents had shown the positive connection with personal experience on occupational hazards 
in health care units. The Electric shock received from electrical equipments during their employment with the test value of .035. The respondents' exposure to radiation from x-ray, radioisotopes sources with the test value of .025. The experience faced in physical difficulties due to lack of ergonomic design of work place with the test value of .014. Respondents experience with the sense of low energy in the work place with the test value of 016. The Employees experience with headache and body pain due to work stress with the test value of .001 . The discomforts faced, due to travel time to employment with the test value of .010. The difficulties to cope up with work demands and family responsibilities with the test value of .000 . The Irregular working hours to compromise family and children with the test value of .000 . All of them, worried about the welfare of children, with the test value of .000 . Finally they were all mentally prepared to work only to meet out economic returns to support their family with the test value of .003 .

The relationship between the 'Employment Experience' of respondents with all identified occupational hazards had shown highest level of significance. There are about sixteen hazards factors showed significance with the dependent factors. The Respondents' had Irritation in their eyes, nose, and throat because of exposure to air borne pathogens with the test value of .000 . The Respondents' had Personal experience over exposure, to blood-borne diseases with the test value of .007 . The Respondents' had experience on lower back pain to carrying heavy loads of work with the test value of .001. The respondents had stressed due to severely disturbed patients, multiple victims of a disaster with the test value of .037. Respondents had faced Osteoporosis due to low bone mineral density with the test value of .008 . Their experience with physical Violence from patients, patient's relatives and others with the test score of .008 . The respondents had experience about emotional abuse from patients and relatives with the test value of .041 . The women employees had their experience with Personal discrimination with the test score of .021. The Women employees had their experience with Personal exploitation with the criterion value of .000 . The Women employees' had exposure to sexual harassment in their place of work with the test value of .010. They faced discomfort during their travel time to employment with the test score of .024. The difficulties to cope up with work demands and family responsibilities with the test value of .000. The Irregular working hours to compromise family and children with the test score of .000 . Respondents had worried about the comfort of their children with the test value of .000 . Respondents had mentally prepared to work only to meet out economic returns to help family with the test value of .000 and finally, the Mental and physical harassment in place of work with the test score of .007.

The relationship between Marital Status of the respondents with identified occupational hazards had shown highest level of significance with the following six hazards factors. The respondents' had exposure to UV radiation with the test value of .034 . The difficulties to catch up with work demands and family responsibilities with the test value of .030 . The lack of support and discouragement resulted out of their family members with the test value of 0.28 . The Irregular working hours to reduce the welfare of family and children with the test value of .000 . The respondents' had worried about the welfare of children, with the test value of .000 . The Respondents had mentally prepared to use only to live out their investment returns to help family with the test value of .000 .

The relationship between "Educational Qualification' with identified occupational hazards had shown highest level of significance with the following five hazards factors. The infectious disease contacts due to close contact with sick patient with the test value of .000 . The blood-borne disease contacts due to blood fluid with the test value of .009. They had exposed to personal exploitation in workplace with the test value of .008 . The difficulties to get up with work demands and family responsibilities with the test value of .003 . The Respondents mentally prepared to use only to settle out economic returns to help family with the test score of .033 .

The relationship between 'various Institution Worked' so for, by the respondents with identified occupational hazards had shown substance with the following fourteen factors. The Physical Injuries due to minor slips, stabs, cuts with the test value of .003. They had distressed due to fear, mental stress, depression, emotional disorder with the test value of .002 . They had experience with electric shock with the test value of .025. Respondents had experienced with skin related problems due to use of soaps, detergents, disinfectants with the test value of .000. Respondents had experienced irritation of eyes, nose, and throat because of exposure to airborne pathogens with the test value of 0.34 . They had an option of contacting an infectious disease due to proximity from sick patient with the test value of .002 . They had exposure to 'Stress' due to severely disturbed patients, multiple victims of a disaster with the test value of .001. Apart from this, the respondents had experienced constantly with head pain and body pain due to work stress with the value of .022 . Women employees had menstrual inconsistency with the test value of .027. They had faced Osteoporosis due to low bone mineral density with the test score of 0.13 . The respondents had exposed to their 'sexual harassment' with the test value of .000. Besides they felt that, it was unsafe profession for women employees with the test score of .000. The respondents faced Mental and physical harassment with the test value of .000 and ultimately the society had their dissenting opinion about women at work with the test value of .000 . 
XI.

CONCLUSION

This study has brought the combined insight of all related hazards class involved with healthcare units. Since, majority of healthcare units had supported with female gender of population, the scope of the study has also limited to women employees. All the research results had supported with facts and figures collected from both levels of primary and secondary sources of investigation. These types of studies always help everyone to plan strategically to achieve the proverb: 'Prevention is better than curing'.

\section{References:}

[1]. WHO, (2005), Integrated Risk Assessment: Report Prepared for the WHO/UNEP/ILO, International Programme on Chemical Safety.

[2]. Occupational Safety and Health Administration (OSHA), (2009), "Guidelines for Nursing Homes: Ergonomics for the Prevention of Musculoskeletal Disorders".

[3]. National Institute for Occupational Safety and Health (NIOSH), (2008), "Exposure to stress: Occupational hazards in Hospital".

[4]. Papp, E.M (2007), "Occupational Health and Safety Management Programme for Nurses", ICHRN eNewsletter, Vol.1 (2).

[5]. Agnihotram, R.V (2005), "An overview of Occupational Health Research in India," Indian journal of occupational and Environmental medicine, Vol.9 (1), 10-14.

[6]. Ramsay, J.D (summer 2005), "A new look at nursing safety: The development and use of JHAs in the Emergency Department", The Journal of SH\&E Research, Vol.2 (2).

[7]. E-Fact 18 - "Risk assessment in Healthcare" (2007), European Agency for safety and health at work.

[8]. Cox (2000), "Research on Work-related Stress", Luxembourg: Office for Official Publications of the European Communities.

[9]. World Health Organization, (2005), Protection of Health Care Workers.

[10]. CRISIL (1999), CRISIL is grading for healthcare institutions.

[11]. Chad J. Roy, (1995), Occupational Health and Safety in the Nursing Home Industry, WORKSAFE IOWA - Occupational Medicine Associates Network, Vol.4 (3). 